\title{
A Prevalence, Intensity, And Associated Of Ectoparasitic Fauna Among Cave-Dwelling Bats From Lombok Island West Nusatenggara
}

\author{
Siti Rabiatul Fajri*, Sucika Armiani \\ Department of Biology Education, Faculty of Applied Science and Engineering, Mandalika \\ University of Education. Jl. Pemuda 59A Mataram 83125 Lombok, Indonesia. \\ *Corresponding Author e-mail: sitirabiatulfajri@ikipmataram.ac.id
}

Received: May 2021; Revised: June 2021; Published: June 2021

\begin{abstract}
The study aimed to observe the prevalence, intensity, and relationship of ectoparasites in bats in the southern region of Lombok Island, West Nusa Tenggara. The study was conducted in March 2018-February 2019. Bat samples were obtained from four caves in the southern part of Lombok Island. These caves include the Galegale Bangkang Cave, Buwun Cave, Semeti Cave, and the Raksasa Cave. Trapping bat samples for identification is done by using the Mist net. While taking ectoparasite samples is done by combing using a toothbrush. The organisms found were collected into sample bottles containing 70\% alcohol. Analysis of the relationship between ectoparasites and bats was done by collecting data on ectoparasite species and ectoparasite abundance in each bat species, then further analysis was carried out to find the value of the Similarity Index (IS). The similarity index found is then cluster analysis. Cluster analysis aims to group based on similarity using Euclidean distance. The results of the study stated that based on the examination of 9 species of bats there were 14 species of ectoparasites identified. The value of the highest prevalence of ectoparasites in Gale-gale Cave Bangkang is found in Cyclopodia horsfieldii at $80 \%$ with an intensity value of 0.63 , in Buwun cave is Amblyomma sp. of $100 \%$ with an intensity value of 1.50 , in Cave Kenculit is Amblyomma sp. of $40 \%$ with an intensity value of 4.25 and in the Raksasa Cave is Cyclopodia horsfieldii of $70 \%$ with an intensity value of 0.71 . While the relationship between the existence of ectoparasites in the bat's body states that the ectoparasite group in the body of bats can be grouped into 5 community groups. Group I consisted of the ectoparasite community in the Macroglossus minimus, and Rosettus an amplxicaudatus with Euclidean distance of 11,916. Group 2, the ectoparasite community was in Miniopterus pusillus, Rhinopoma microphyllum and Rhinolopus acuminatus with Euclidean distance of 15,362. Group 3 ectoparasite communities in the Chaerephon plicata and Taphozous melanopagon with Euclidean distances of 6,000. Group 4, the ectoparasite community only inhabited Eonycteris spelaea with Euclidean distance of 27,423. And group 5 also only inhabits Rhinolopus simplex with Euclidean distance of 46,293.
\end{abstract}

Key Word: Prevalence, Associated, Ectoparasites, Bat, Lombok West Nusatenggara

How to Cite: Fajri, S., \& Armiani, S. (2021). A Prevalence, Intensity, and Associated of Ectoparasitic Fauna Among Cave-Dwelling Bats from Lombok Island West Nusa Tenggara. Prisma Sains : Jurnal Pengkajian Ilmu dan Pembelajaran Matematika dan IPA IKIP Mataram, 9(1), 141-151. doi:https://doi.org/10.33394/jps.v9i1.3897

\section{INTRODUCTION}

Bats is one of the orders from the class of mammals that have the ability to move by using wings (flying). In general, bats belonging to the Order of Chiroptera can be grouped into 2 Sub-orders, namely Sub-order Megachiroptera (Fruit-eater) and sub-order Microchiroptera (Insectivorous) (Suyanto et al., 2001). Bats in Indonesia are estimated to reach 230 species or $21 \%$ of the bat species in the world. The species included 77 species 
grouped into the Megachiroptera sub-order while 153 species were grouped into the Microchiroptera sub-order (Suyanto et al., 2001)

The role of bats and colonizing life habits make bats interact with other living things so as to facilitate the spread and transmission of parasitic infections, both endoparasites, and ectoparasites. Ectoparasites which can infect bats are generally classified into 2 classes in Arthropod phylum, namely Insecta and Arachnida such as bat fleas, flies, mites, and ticks which can be a vector of the spread of diseases caused by bacteria, protozoa, and viruses to humans or other animals (Mathison \& Pritt, 2014)

Previous research in several regions in Indonesia found several types of ectoparasites in bats. In the Tesso Nilo area, Riau Province with the type of Ballonycteris maculata found two types of ectoparasites from the Nycteribiidae family (Suyanto et al., 2001). Research in the Indonesia University, Depok campus area with bats from Genus Cynopterus and Macroglossus found two types of ectoparasites from the Nycteribiidae family, namely horsfieldii Cyclopodia and Leptocyclopodia ferrarrii (Putra, 2014). Another study, in Anjani Cave, Central Java, consisted of three species of bats namely Rhinolophus sp., Hipposideros larvatus, and Hipposideros sp. found 1 ectoparasite genus, Ectopsocopsis sp. from Ectopsocidae family (Sari et al., 2015). Meanwhile, research in the Lombok area is still very minimal, recorded two studies, mentioning that there are 3 species of ectoparasites namely Megistopoda aranae, Dermacentor sp., and Nycteribia kolenati (Poerwanto et al., 2020) and mentioning that of the 2 types of bats studied were Macroglossus minimus and Eonycteris spelaea there were 4 types of ticks namely Ixodes sp., Amblyomma sp., Dermacentor sp., and Rhipicephalus sp.

Furthermore, research on ectoparasites in bats has been carried out in several countries in the world. For example, in Brazil, it was noted that from 2 family Phyllostomidae and Mormoopidae examined, namely Artibeus planirostris and Carolia perspicillata there were 5 species of tick that were identified including Nothoaspis amazoniensis, Ornithodoros cavernicolous, Ornithodoros fonsecai, Ornithodoros hasei, and Ornithodoros marinkellei (H. R. Luz et al., 2016). Furthermore, in Central Europe, based on examination of 4 bats of Miniopterus schreibersii, Myotis blythii, Myotis capaccinii and Rhinolophus ferrumequinum, there were 45 bat flies that were successfully identified (Haelewaters et al., 2017). In the Philippines of 150 bats captured in 11 caves there were 11 species of ectoparasites that were identified among them from the arthropod class, there were 587 ectoparasites representing 21 species, and 5 families (Acari: Argasidae and Spinturnicidae; Diptera: Nycteribiidae and Streblidae; and Siphonaptera: Ischnopsyllidae). The new record include 10 ectoparasite species including Brachytarsina cucullata (Jobling 1934), B. proxima (Jobling, 1951), B. werneri (Jobling 1951), Raymondia pseudopagodarum (Jobling 1951), Eucampsipoda philippinensis (Ferris 1924), Nycteribia allotopa (Speiser 1901), Nycteribia allotopoides (Theodor 1963), Nycteribia parvuloides (Theodor 1963), Ancystropus taprobanius (Turk 1950), and Carios batuensis (Hirst 1929) (Amarga et al., 2017).

Based on the description above, thus researchers are interested in conducting ectoparasitic research of bats in 4 caves in the southern region of Lombok Island. This study aimed to exfoliate parasites in bats, including the prevalence of ectoparasites, the intensity of ectoparasites in the bat's body and the relationship of ectoparasites to bats. This study is expected to provide information on emergence disease seen from the results of the identification of how many parasites infect bats.

\section{METHOD}

\section{Study Area}

Bats were collected from Raksasa Cave, located in Tanjung Ringgit, Gale-gale Bangkang cave in Prabu village, Buwun Cave in Prabu village, and Kenculit cave on the Semeti Beach of Southern of Lombok in Maret 2018 to February 2019. Below is the map of the research site in Figure 1. 


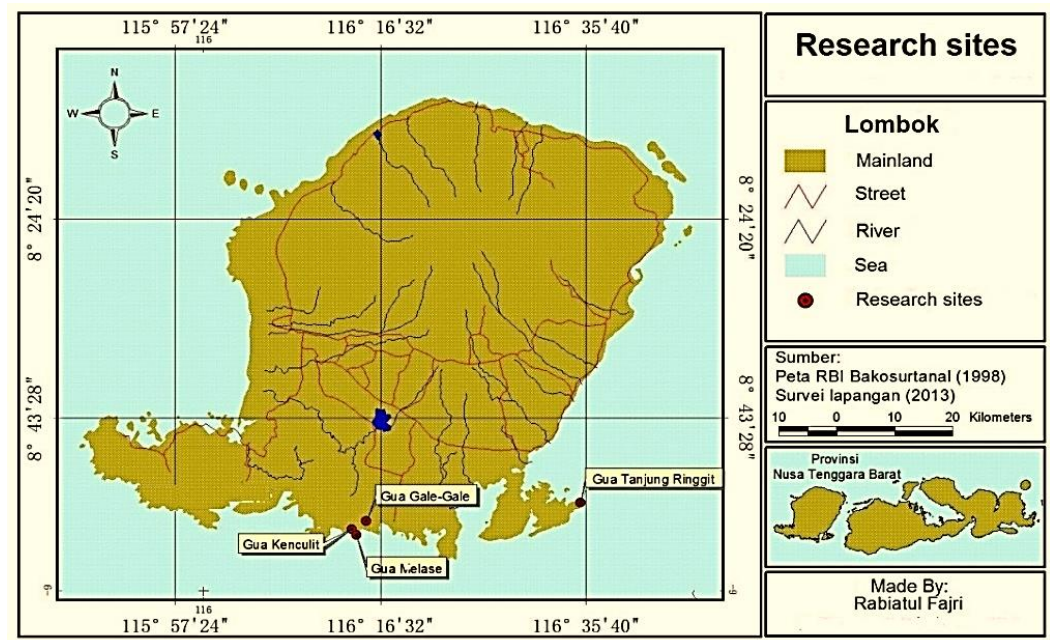

Figure 1. Research sites

\section{Procedures}

Bats were collected by trapping using mist net. The net was set up at the gate of the cave at 06.00-07.00 PM (Fajri et al., 2014). The bats those were trapped in the net were removed and collected inplastic bags then deeply anesthetized using chloroform. The bats were transported to Laboratory of Biology, Faculty of Mathematics and Natural Sciences University of Mataram. The bat specimens then identify referred to (Suyanto et al., 2001) and (Kitchener, 1990).

The hairs of anesthetized-bats were swapped using alcohol $70 \% \mathrm{v} / \mathrm{v}$. The hairs then combed using tooth comb gently. The parasites collected from bats' hairs were kept in effendorf tube contained alcohol $70 \%$. The ectoparasites specimens were observed under microscope (USB Microscope Digital 1000x). The ectoparasites identification was referred to (Klimpel \& Mehlhorn, 2014). Data of ectoparasites, number and host, collected from the hairs of bat were tabulated. Each species of parasite were described separately.

\section{Data Analysis}

The parasitic prevalence and intensity were calculated using the Kabata formula (1985), whereas to analyze the relationship of ectoparasites with bats was the data of ectoparasite species and ectoparasite abundance in each bat species, further analysis was carried out to find the similarity index (IS) value. Found was then performed cluster analysis. Cluster analysis for classifying based on similarity using Euclidean distance. The ecology indices and statistical analyses were performed using PAST 3.02a.

\section{RESULTS AND DISCUSSION}

The bat species collected from 4 caves Southern of Lombok during field work period of Maret 2018 to February 2019. A total of 153 insect and Arachnida ectoparasites (Table 1), were obtained from 90 individuals of cave bats representing 9 species of bat. We could identify them as ten species that are infected with ectoparasites of E. spelaea, M. minimus, $R$. ampexicaudataus, Rhinolopus simplex, Rhinopoma microphyllum, Rhinolopus acuminatus, Chaerephon plicata, Taphozous melanopogon, and Miniopterus pusillus.

The value of the highest prevalence of ectoparasites in Gale-gale Bangkang Cave is found in Cyclopodia horsfieldii (Meigere, 1899) at $80 \%$ with an intensity value of 0.63 , in Buwun cave is Amblyomma sp. (Murray, 1844) of $100 \%$ with an intensity value of 1.50 , in Cave Kenculit is Amblyomma sp. (Murray, 1844) of $40 \%$ with an intensity value of 4.25 and in the Raksasa Cave is Cyclopodia horsfieldii (Meigere, 1899) of $70 \%$ with an intensity value of 0.71. In addition, in the table also seen Meristaspis lateral (Kolenati, 1856) has the highest intensity value of 6.00 and the lowest is Ancystropus zeleborii (Kolenati, 1856) of 0.33 (Ind.). More detailed in Table 1 below. 
Table 1. Prevalance and Intensity Ectoparasites.

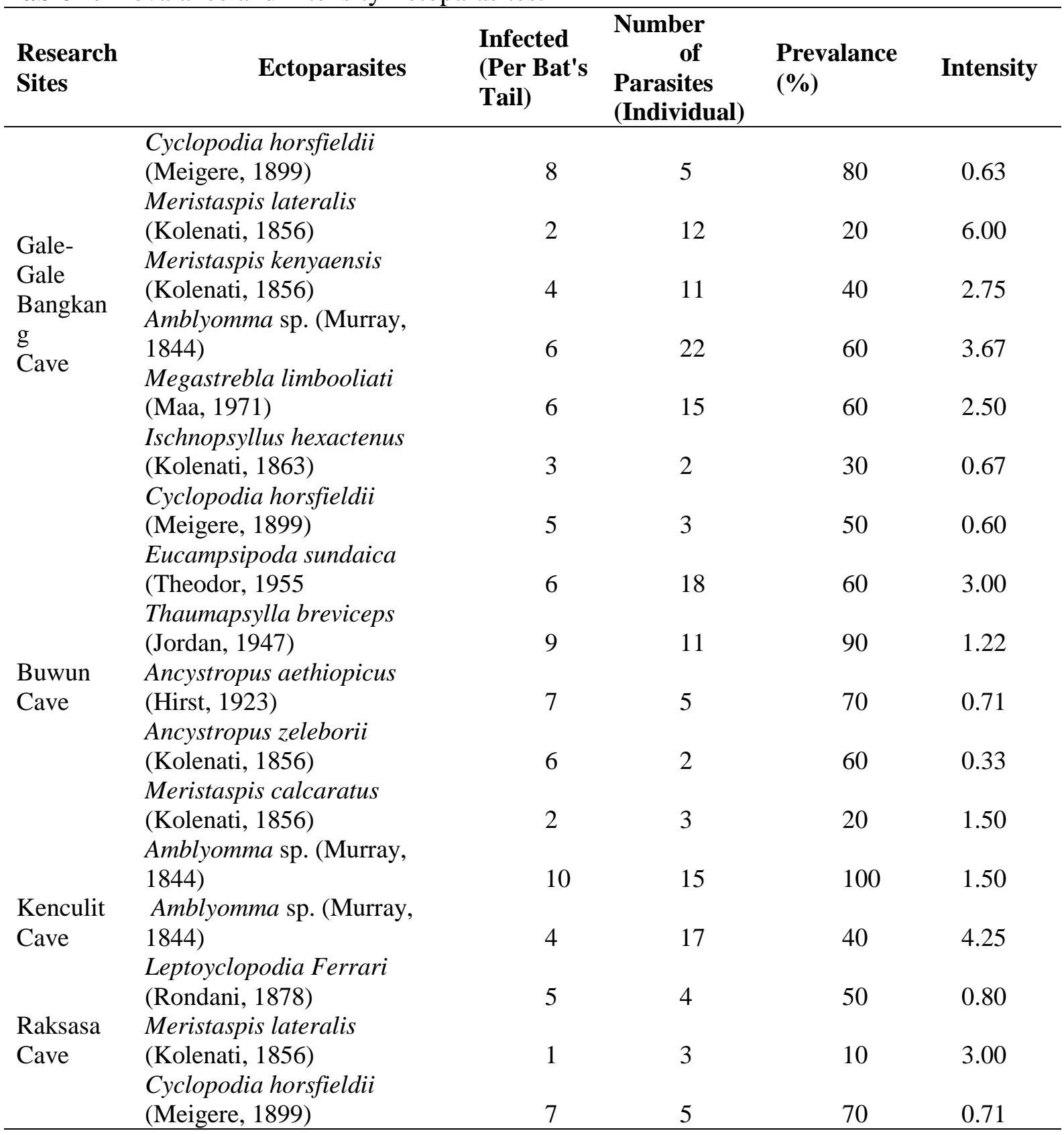

Based on the similarity index value, then performed cluster analysis.Cluster analysis results can be seen in Figure 1 dendogram ectoparasites.

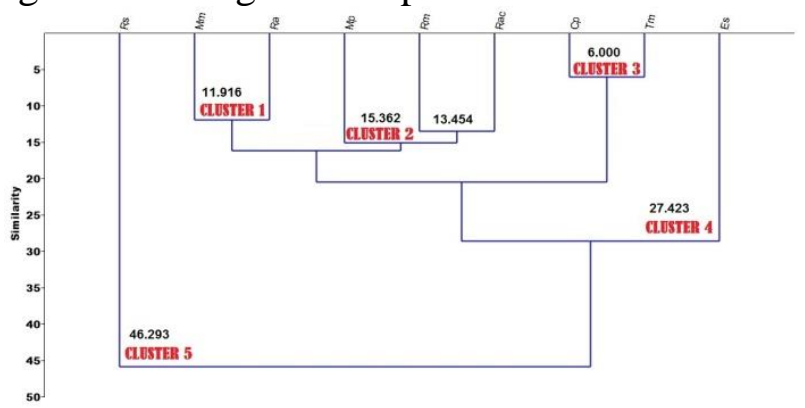

Figure 2. Dendogram Ectoparasites

Note: Es: Eonycteris spelaea, Mm: Macroglossus minimus, Ra: Rosettus a amplxicaudatus, Mp: Miniopterus pusillus, Rm: Rhinopoma microphyllum, Rs: Rhinolopus simplex, Cp: Chaerephon plicata, Tm: Taphozous melanopagon, Rac: Rhinolopus acuminatus (PAST 3.02a) 
Based on Figure 2, it is stated that the ectoparasite group in the body of bats in the southern region of Lombok Island can be grouped into 5 community groups. Cluster 1 consisted of ectoparasite communities in Macroglossus minimus, and Rosettus a amplxicaudatus with Euclidean distances of 11,916. Cluster 2, the ectoparasite community was in Miniopterus pusillus, Rhinopoma microphyllum and Rhinolopus acuminatus with a Euclidean distance of 15,362. Cluster 3 of the ectoparasite community in Chaerephon plicata and Taphozous melanopagon with Euclidean distances of 6,000. Cluster 4, the ectoparasite community only inhabited Eonycteris spelaea with a Euclidean distance of 27,423. And Cluster 5 also only inhabited Rhinolopus simplex with the Euclidean distance of 46,293.

Bats are one of the animals that has high activity and very wide distribution. Several bat species can live together with thousands of individuals in one cave (Findley, 1993). These make them natural reservoirs of many ectoparasites such as ticks, mites, chiggers, bugs, fleas, and flies (Dick et al., 2003). Many ectoparasites of bats are potential vector-borne which transmit numerous diseases to other animals both wildlife and domestic animals.

A total of 153 individual ectoparasites were identified in 9 bat species. Ectoparasites consist of 2 classes and 4 orders. Both classes of ectoparasites include insect and arachnid classes. While the four orders include the order Diptera, Siphonaptera, Ixodida, and Mesostigmata. Bat flies dominate any previous study of ectoparasites in bats. Recorded 19 species of bat flies from bats in São Paulo, Brazil (Bertola et al., 2005). Furthermore, according to who studied bat ectoparasites in Kanchanaburi, Thailand, only 2 individual ectoparasites from 23 bats were found. Bat flies are the most common ectoparasites of bats in this area, followed by mites (Changbunjong et al., 2010). This data corroborates with the study of who reported that mites and bat flies were common ectoparasites in bats, whereas ticks were rarely observed in bats (Autino et al., 2011). Many studies also show that bat flies and mites are the most abundant bat ectoparasites. Took a sample of 10 species of bat bats and 11 species of mites from bats in southeastern Brazil. In addition, (Moras et al., 2013) found 14 species of bats and 9 species of mites from bats in southern Minas Gerais, Brazil and most recently (Aroon et al., 2015) mentioned that of the 66 individual bats that were fixed on SBR, consisting of fly bats $(n=57)$, mites $(n=6)$ and lice $(n=1)$ and only one ixodid louse. Unlike the results of this study, there were 61 individual ticks identified. Whereas, the presence of several ectoparasites not found in this study may be due to the low number of hosts caught.

Several factors could effect the host preference was host sexual, age, intra and inter species interaction of the host and the host behavior. Ectoparasite preference on the female bat as the host is the grooming behavior. This behavior could be a defensive mechanism against the parasites. However, grooming behavior exhibited by female bats could be exhausted their calories, less aware to predators, and could be losing their hair (ter Hofstede \& Fenton, 2005). Female bats tent to save their calories for infant nourishing (Piksa et al., 2011). Showed those male bats groom more than those female (Czenze \& Broders, 2011). The can expedite their extra calories for grooming which may expel the more parasites (Christe et al., 2007). but different as disclosed (Lourenço \& Palmeirim, 2007) reported 2 species of bat colonies were observed Miniopterus schreibersii and Spinturnix psi. states that if both bats during reproduction are exposed to ectoparasites, they will lose $10 \%$ of their body weight. It would be very detrimental to the bat colony especially being on time to reproduce offspring. But if not during the reproductive period will cause a negative correlation with the presence of ectoparasites.

The parasites could develop the two strategies to infest fit host (adult bats) or vulnerable host (sub-adult bats). the adult bats more infested with ectoparasites rather than sub-adult. It is, however, to infest the fit host is more advantageous for a longer period than those vulnerable ones (J. L. Luz et al., 2009). In the other word, ectoparasites could prefer to infest the adult bats rather than sub adult ones. Contrarily (Czenze \& Broders, 2011; Findley, 1993) showed that ectoparasites preference to sub-adult bats was high. This strategy is 
affected by their roosting location is shared with an adult female. On the other hand, the subadult bats have been observed not exhibited the grooming behavior. These factors could be the advantages for ectoparasites to infest the sub-adult bats. The foraging behavior of bats could be also one factor in the ectoparasits transfer. Bats could share the feeding trees and expelled the parasite. When the other individual of bats foraged in the same trees, the parasite could infest the other bats (Olival et al., 2013)

The preference of ectoparasites to infested their host could be caused by their adaptation to host condition. The ectoparasites from family Nycteribiidae is highly dependence to the host which provide the nutrients (Stanko et al., 2002). The location on the body part of the host also affected the preference of parasite. According to (Kasso \& Balakrishnan, 2013), body part with the dense hair of the host is preferred by parasites. They could to hide securely and it is very difficult to approach on grooming activity.

The ectoparasites found in bats are very diverse, different species of bats will be inhabited by different types of ectoparasites. as reported by the (Jaunbauere et al., 2008) study, there are 12 species from 4 families (insects and mites/ticks). Ectoparasites include Spinturix myoti, Periglischirus spp, Trombiculidae (Lice), Steatonyssus cavus, Macronyssus crosbyi, Nycteribia pedicularia, Ischnopsyllus hexactenus, Myodopsylla trisellis and Ixodes persulcatus. Ectoparasites were found in bats of species Eptesicusnilssoni, Plecotusauritus, Pipistrellusnathusii, Myotis crosbyi, Myotis mystacinus, Myotis daubentoni and $M$. dasycneme. Furthermore (Kurta et al., 2007) added a collection of ectoparasites in fresh bats including: Macronyssus crosbyi, Alabidocarpus calcaratus, Acanthophthirius lucifugus, Pteracarus nr. Minutes, Spinturnix americanus, Leptotrombidium myotis, Myodopsylla gentilis, Cimex pilosellus, Basilia forcipata, Ornithodoros sp., Glycyphagus hypudaei, and Alabidocarpus $n r$. Eptesicus. Ectoparasite faunal survey of bats for Marinduque Island, Philippines representing 21 species, belonging to five families (Acari: Argasidae and Spinturnicidae; Diptera: Nycteribiidae and Streblidae; and Siphonaptera: Ischnopsyllidae) were collected. New host records (new host record) in the Philippines for Brachytarsina cucullata Jobling 1934, B. proxima Jobling 1951, B. werneri Jobling 1951, Raymondia pseudopagodarum Jobling 1951, Eucampsipoda philippinensis Ferris 1924, Nycteribia allotopa Speiser 1901, Nycteribia allotopoides Theodor 1963, Nycteribia parvuloides Theodor 1963, Ancystropus taprobanius Turk 1950, and Carios batuensis Hirst 1929 (Amarga et al., 2017).

Value of the highest prevalence of ectoparasites in Gale-gale Bangkang Cave is found in Cyclopodia horsfieldii ectoparasites (Meigere, 1899) at $80 \%$ with an intensity value of 0.63, in Buwun cave is Amblyomma sp. (Murray, 1844) of $100 \%$ with an intensity value of 1.50, in Kenculit Cave is Amblyomma sp. (Murray, 1844) of $40 \%$ with an intensity value of 4.25 and in the Raksasa Cave is Cyclopodia horsfieldii (Meigere, 1899) of 70\% with an intensity value of 0.71 . In addition, in the table also seen Meristaspis lateral (Kolenati, 1856) has the highest intensity value of 6.00 and the lowest is Ancystropus zeleborii (Kolenati, 1856) of 0.33 .

Cyclopodia horsfieldii (Meigere, 1899) has the highest prevalence value for ectoparasites in the Gale-gale Bangkang Cave and at the Raksasa Cave in Tanjung Ringgit. Of the 10 bats samples examined, 8 bats was infected with the ectoparasites. Cyclopodia horsfieldii is commonly found in species of Cynopterus bat. But it has also been reported in the Bats of Pteropus, Acerodon and Rousettus, new hosts including Cynopterus brachyotis and Ptenochirus columns (Kurta et al., 2007). Where as in this Cyclopodia horsfieldii are found in the species Eonycteris spelaea, Rosettus amplexicaudatus, and Miniopterus pusillus. The spread of Cyclopodia horsfieldii has been found in the Philippines including Luzon, Mindoro, Busuanga, Culion, Palawan, Balabac, Leyte, Iloilo, Panay, Guima-ras, Camiguin, Mindanao, Negros and Jolo (Nadchatram \& Mitchell, 1965). In addition, around the mountains in Indonesia, Cambodia, Malaysia, Thailand and Timor Leste (Fritz, 1983). 
Amblyomma sp. (Murray, 1844) has the highest prevalence value for ectoparasites in Buwun Cave. Of the 10 bats examined all bats were infected with this ectoparasite. Amblyomma sp. vector of Francisel latularensis namely tularemia and Ehrlichiach affeensis agent which causes monocyticehrlichiosis in humans. This tick also transmits Rickettsia amblyommii, Borrelialonestari, and Heartland viruses that cause disease in humans (Fritz, 1983). The Mesostigmata Order has the largest number of parasitic species whose members are mostly blood-sucking at the adult stage [Noble and Noble, 1989]. Amblyomma sp is found in several species of bats including Rousettes egyptian (Rousettus aegyptiacus), Eonycteris spelaea, Chaerephon plicata, and Taphozous melanopagon (Fajri et al., 2018).

Meristaspis lateral (Kolenati, 1856) has a high-intensity value in the Gale-gale Bangkang cave. Although the number of bats infected is only 2, the level of presence in infected bats is quite high. Meristaspis lateral is commonly found in Rousettus aegyptiacus (Negm \& Fakeer, 2014). While in this study it was found in the Macroglossus minimum and Rosettus a amplxicaudatus.

Bats are excellent models for studying host-parasite relationship because their taxonomy and behaviors are extremely diverse (Kim et al., 2012). In Southeast Asia, about $30 \%$ of the total bat species in the world were documented (320 species)(Mariana et al., 2005). However, there is a lack of data on ectoparasites associated with bats in tropical regions, particularly in Southeast Asia (Uchikawa \& Kobayashi, 1979). Hence, studying the host-parasite relationships between bats and their ectoparasites is important information in biology, systematics, and phylogeny of their hosts (Zabat \& Eduardo, 2011). Moreover, data on ectoparasites of bats are needed to determine their role as vectors of zoonotic pathogens (Jordan, 1947).

The type of ectoparasites found in Macroglossus minimus in this study was Leptoyclopodia Ferrari and Meristaspis lateralis. In addition to the two types of ectoparasites found in this study, Macroglossus minimus bats have reported the presence of other ectoparasites including ectoparasites from the order Mesostigmata species Spinturnicid mites (Maa, 1962).

The type of ectoparasite found in Eonycteris spelaea in this study was Cyclopodia horsfieldii, Eucampsipoda sundaica, Thaumapsylla breviceps, Amblyomma sp., Ancystropus aethiopicus, Ancystropus zeleborii, and Meristaspis calcaratus. The seven types of ectoparasites found in this study have also been previously reported by Uchikawa \& Tsuneaki (Maa, 1971a) in Thailand. In addition, several types of ectoparasites found in Eonycteris spelaea have also been reported in Rosettus a amplxicaudatus such as ectoparasite species, Ancystropus zeleborii, Eucampsipoda sundaica, and, Thaumapsylla breviceps (Maa, 1971b) . This is because Eonycteris spelaea and Rosettus a amplxicaudatus perch are adjacent and side by side.

The type of ectoparasite found in Rosettus a amplxicaudatus in this study were three species of ectoparasites including Cyclopodia horsfieldii, Meristaspis lateralis, and Meristaspis kenyaensis. In addition to the three species of ectoparasites found in this study, Rosettus a amplxicaudatus have reported the presence of other types of ectoparasites. The ectoparasites were identified as follows: Two species of bat flies, Eucampsipoda sundaicum and Megastrebla parvoir belonging to the families Streblidae and Nycteribidae, respectively; a species of flea, Thaumapsylla breviceps of the family Ceratophyllidae, two species of mites, lateral cysts and Ancystropus zellabhorii both belonging to the family Spinturnicides and unidentified tick larvae belonging to the family Ixodidae (Maa, 1975).

E. sundaica has been reported to find in India, Myanmar, Laos, Cambodia, Thailand, Malaysia, Indonesia, and New Guinea. They have species-specifically host-parasite relationship with E.spelaea and $R$. amplexicaudatus (Scheffler et al., 2016). L. Ferrari has been reportedto be found in Cambodia, Thailand, Malaya, Borneo, and Java collected in Cynopterus brachyotis (Delfinado \& Baker, 1963). Thaumapsyla breviceps (Amarga et al., 2017) has reported the parasite have been found in the bat of genus Eonycteris and Rousettus. 
However, in this recent study, the parasite was only found in E. Spelaea. Distribution is Megastrebla limbooliati collected from Eonycteris major in Borneo, Serawak, Cynopterus sp in Ceylon, Hipposideros sp in Malaya (Benda et al., 2010). Chiefly parasitic on Rhinolophidae: Rhinolophus, less often on Hipposideridae: Hipposideros. Three of the 85 paratypes were originally recorded [43] as from Rousettus amplexicaudatus E. Geoffr, or Eonycteris spelaea glandifera Lawrence in the Philippines: Mindanao. Raymondia pseudopagodarum collected from Rhinolophus sap in Cantor, Sitio Tegato, Davao City, Mindanao, Philippines (Benda et al., 2010; Scheffler et al., 2016).

A new report from (Amarga et al., 2017) Raymondia pseudopagodarum collected from Eonycteris spelaea, Emballanura Alecto (new host record), Hipposideros ater (new host record), Hipposideros galeratus, Miniopterus Australis, M. schreibersi, Rhinolophus arcuatus, R.philippinensis (new host record), R.rufus, R.virgo.Two bat fly species have been collected. Nycteribia pedicularia have been found on Myotis daubentoni and M. dasycneme. The single specimen of Nycteribia biarticulata has been collected on Myotis dasycneme. Two bat fleas Ischnopsyllus hexactenus and Myodopsylla trisellis were recorded. I. hexactenus were found on five, but M. trisellis on two bat species (Jaunbauere et al., 2008). Bats that once hosted Ischnopsyllus hexactenus were Myotis frater and Murina hilgendorfi (Scheffler et al., 2016) and Pipistrellus pipistrellus (Benda et al., 2010). This study also became the first study to report the existence of Ischnopsyllus hexactenus (The long Eared Bat Flea) in the bat species of $R$. microphyllum. Ischnopsyllus hexactenus is an ectoparasite that can be a vector of some pathogenic bacteria zoonosis including trypanosomes. The abundance of Ischnopsyllus hexactenus in bats is quite high, even able to make bats as its sole host (Fajri et al., 2018).

\section{CONCLUSION}

The conclusions of the research that based on examination of 9 species of bats there were 14 species of ectoparasites identified. The value of the highest prevalence of ectoparasites in Gale-gale Cave Bangkang is found in Cyclopodia horsfieldii (Meigere, 1899), in Buwun cave is Amblyomma sp. Murray, 1844), in Cave Kenculit is Amblyomma sp. and in the Raksasa Cave is Cyclopodia horsfieldii (Meigere, 1899). In addition, Meristaspis lateral (Kolenati, 1856) has the highest intensity value of 6.00 and the lowest is Ancystropus zeleborii (Kolenati, 1856) of 0.33 . While the relationship between the existence of ectoparasites in the bat's body states that the ectoparasite group in the body of bats can be grouped into 5 community groups. Group I consisted of the ectoparasite community in the Macroglossus minimus, and Rosettus an amplxicaudatus. Group 2, the ectoparasite community was in Miniopterus pusillus, Rhinopoma microphyllum and Rhinolopus acuminatus. Group 3 ectoparasite communities in the Chaerephon plicata and Taphozous melanopagon. Group 4, the ectoparasite community only inhabited Eonycteris spelaea and group 5 also only inhabits Rhinolopus simplex.

\section{ACKNOWLEDGMENT}

We thank our RISTEKDIKTI for the support the research found. The Chairman of coauthor for the writing and research guidance. In addition, and I thank to the lectures of Mataram University for the support in research.

\section{REFERENCES}

Amarga, A. K. S., Alviola, P. A., Lit, Jr., I. L., \& Yap, S. A. (2017). Checklist of ectoparasitic arthropods among cave-dwelling bats from Marinduque Island, Philippines. Check List, 13(1), 2029. https://doi.org/10.15560/13.1.2029

Aroon, S., Iii, J. G. H., Artchawakom, T., Kupittayanant, S., \& Thanee, N. (2015). Ectoparasites associated with bats in tropical forest of northeastern Thailand. 11, 12. 
Autino, A. G., Claps, G. L., Barquez, R. M., \& Díaz, M. M. (2011). Ectoparasitic insects (Diptera: Streblidae and Siphonaptera: Ischnopsyllidae) of bats from Iquitos and surrounding areas (Loreto, Peru). Memórias Do Instituto Oswaldo Cruz, 106(8), 917925. https://doi.org/10.1590/S0074-02762011000800004

Benda, P., Lučan, R., Obuch, J., Reiter, A., Andreas, M., Bačkor, P., Bohnenstengel, T., Eid, E., Ševčík, M., Vallo, P., \& Amr, Z. (2010). Bats (Mammalia: Chiroptera) of the Eastern Mediterranean and Middle East. Part 8. Bats of Jordan: fauna, ecology, echolocation, ectoparasites. Undefined. /paper/Bats-(Mammalia\%3A-Chiroptera)-ofthe-Eastern-and-Part-Benda-

Lu\%C4\%8Dan/d81bb9c2a2671d60216e853336f38704bfbf1144

Bertola, P. B., Aires, C. C., Favorito, S. E., Graciolli, G., Amaku, M., \& Pinto-da-Rocha, R. (2005). Bat flies (Diptera: Streblidae, Nycteribiidae) parasitic on bats (Mammalia: Chiroptera) at Parque Estadual da Cantareira, São Paulo, Brazil: parasitism rates and host-parasite associations. Memórias Do Instituto Oswaldo Cruz, 100(1), 25-32. https://doi.org/10.1590/S0074-02762005000100005

Changbunjong, T., Jirapattharasate, C., Buddhirongawatr, R., Chewajon, K., Charoenyongyoo, P., Suwanapakdee, S., Waengsothorn, S., Triwitayakorn, K., Chaichoun, K., \& Ratanakorn, P. (2010). Ectoparasitic fauna of birds, and volant and non-volant small mammals captured at Srinakarin Dam, Kanchanaburi, Thailand. The Southeast Asian Journal of Tropical Medicine and Public Health, 41(3), 526-535.

Christe, P., Glaizot, O., Evanno, G., Bruyndonckx, N., Devevey, G., Yannic, G., Patthey, P., Maeder, A., Vogel, P., \& Arlettaz, R. (2007). Host sex and ectoparasites choice: Preference for, and higher survival on female hosts. Journal of Animal Ecology, 76(4), 703-710. https://doi.org/10.1111/j.1365-2656.2007.01255.x

Czenze, Z. J., \& Broders, H. G. (2011). Ectoparasite Community Structure of Two Bats ( Myotis lucifugus and M. septentrionalis ) from the Maritimes of Canada. Journal of Parasitology Research, 2011, 1-9. https://doi.org/10.1155/2011/341535

Delfinado, M. D., \& Baker, E. W. (1963). MITes Of The Family Spinturnicidae From The. Pacific Insects, 5(4), 16.

Dick, C. W., Gannon, M. R., Little, W. E., \& Patrick, M. J. (2003). Ectoparasite Associations of Bats from Central Pennsylvania. Journal of Medical Entomology, 40(6), 813-819. https://doi.org/10.1603/0022-2585-40.6.813

Fajri, S. R., Idrus, A. A., \& Hadiprayitno, G. (2014). Kelimpahan Spesies Kelelawar Ordo Chiroptera di Gua Wilayah Selatan Pulau Lombok NTB. JURNAL BIOLOGI TROPIS, 14(2). https://doi.org/10.29303/jbt.v14i2.136

Fajri, S. R., NPrimawati, S., Hadi, I., \& Tresnani, G. (2018). New Record Of Rhinopoma microphyllum With The Invested Parasites And Microbes In The Developed Ecotourism Area Of South Lombok Island NTB. Journal of Physics: Conference Series, 953, 012011. https://doi.org/10.1088/1742-6596/953/1/012011

Findley, J. S. (1993). Bats: A community perspective. Cambridge University Press.

Fritz, G. N. (1983). Biology and Ecology of Bat Flies (Diptera: Streblidae) on Bats in the Genus Carollia1. Journal of Medical Entomology, 20(1), 1-10. https://doi.org/10.1093/jmedent/20.1.1

Haelewaters, D., Pfliegler, W. P., Szentiványi, T., Földvári, M., Sándor, A. D., Barti, L., Camacho, J. J., Gort, G., Estók, P., Hiller, T., Dick, C. W., \& Pfister, D. H. (2017). Parasites of parasites of bats: Laboulbeniales (Fungi: Ascomycota) on bat flies (Diptera: Nycteribiidae) in central Europe. Parasites \& Vectors, 10(1), 96. https://doi.org/10.1186/s13071-017-2022-y

Jaunbauere, G., Salmane, I., \& Spu, V. R. (2008). Occurrence of Bat Ectoparasites in Latvia. 5. 
Jordan, K. (1947). On Thaumapsyllinae, a new subfamily of bat fleas (Suctoria, Ischnopsyllidae). Proceedings of the Entomological Society of Washington, 49, 182184.

Kasso, M., \& Balakrishnan, M. (2013). Ecological and Economic Importance of Bats (Order Chiroptera). ISRN Biodiversity, 2013, 1-9. https://doi.org/10.1155/2013/187415

Kim, H. C., Han, S. H., Dick, C. W., Choi, Y. G., Chong, S. T., Klein, T. A., \& Rueda, L. M. (2012). Geographical distribution of bat flies (Diptera: Nycteribiidae and Streblidae), including two new records, Nycteribia allotopa and $N$. formosana, collected from bats (Chiroptera: Rhinolophidae and Vespertilionidae) in the Republic of Korea. Journal of Vector Ecology, 37(2), 333-337. https://doi.org/10.1111/j.1948-7134.2012.00235.x

Kitchener, D. J. (Ed.). (1990). Wild mammals of Lombok Island: Nusa Tenggara, Indonesia: systematics and natural history. Western Australian Museum.

Klimpel, S., \& Mehlhorn, H. (Eds.). (2014). Bats (Chiroptera) as Vectors of Diseases and Parasites: Facts and Myths (1st ed. 2014). Springer Berlin Heidelberg: Imprint: Springer. https://doi.org/10.1007/978-3-642-39333-4

Kurta, A., Whitaker, J. O., Wrenn, W. J., \& Soto-centeno, J. A. (2007). Ectoparasitic Assemblages on Mormoopid Bats (Chiroptera: Mormoopidae) from Puerto Rico. Journal of Medical Entomology, 44(6), 953-958. https://doi.org/10.1093/jmedent/44.6.953

Lourenço, S. I., \& Palmeirim, J. M. (2007). Can mite parasitism affect the condition of bat hosts? Implications for the social structure of colonial bats. Journal of Zoology, 273(2), 161-168. https://doi.org/10.1111/j.1469-7998.2007.00322.x

Luz, H. R., Muñoz-Leal, S., Almeida, J. C. de, Faccini, J. L. H., \& Labruna, M. B. (2016). Ticks parasitizing bats (Mammalia: Chiroptera) in the Caatinga Biome, Brazil. Revista Brasileira de Parasitologia Veterinária, 25(4), 484-491. https://doi.org/10.1590/s198429612016083

Luz, J. L., Costa, L. de M., Gomes, L. A. C., \& Esbérard, C. E. L. (2009). The chiggerflea Hectopsylla pulex (Siphonaptera: Tungidae) as an ectoparasite of free-tailed bats (Chiroptera: Molossidae). Memórias Do Instituto Oswaldo Cruz, 104(4), 567-569. https://doi.org/10.1590/S0074-02762009000400005

Maa, T. C. (1962). Records And Descriptions Of Nycteribiidae. 20.

Maa, T. C. (1971a). An Annotated Bibliography Of Batflies (Diptera-[PDF Document]. Vdocuments.Net. https://vdocuments.net/an-annotated-bibliography-of-batflies-diptera.html

Maa, T. C. (1971b). Review of The Streblidae (Diptera) Parasitic on Megachiropteran Bats.

Maa, T. C. (1975). On new Diptera pupipara from the Oriental region. Pacific Insects. https://agris.fao.org/agris-search/search.do?recordID=US201302740515

Mariana, A., Zuraidawati, Z., Ho, T. M., Mohd Kulaimi, B., Saleh, I., Shukor, M. N., \& Shahrul-Anuar, M. S. (2005). A survey of ectoparasites in Gunung Stong Forest Reserve, Kelantan, Malaysia. The Southeast Asian Journal of Tropical Medicine and Public Health, 36(5), 1125-1131.

Mathison, B. A., \& Pritt, B. S. (2014). Laboratory Identification of Arthropod Ectoparasites. Clinical Microbiology Reviews, 27(1), 48-67. https://doi.org/10.1128/CMR.00008-13

Moras, L., Bernardi, L., Graciolli, G., \& Gregorin, R. (2013). Bat flies (Diptera: Streblidae, Nycteribiidae) and mites (Acari) associated with bats (Mammalia: Chiroptera) in a high-altitude region in southern Minas Gerais, Brazil. Acta Parasitologica, 58(4). https://doi.org/10.2478/s11686-013-0179-x

Nadchatram, M., \& Mitchell, C. J. (1965). New Bat Chiggers From Thailand and the Solomon Islands with Notes on the Subgenus Sasatrombicula Vercammen-Grandjean (Acarina: Trombiculidae)1. Journal of Medical Entomology, 2(1), 70-74. https://doi.org/10.1093/jmedent/2.1.70 
Negm, M. W., \& Fakeer, M. M. (2014). Rediscovery of Meristaspis Lateralis ( Kolenati ) ( Acari: Mesostigmata: Spinturnicidae ) Parasitizing the Egyptian Fruit Bat, Rousettus Aegyptiacus ( Geoffroy ) ( Mammalia: Chiroptera), with a Key to Mites of Bats in Egypt. Journal of the Egyptian Society of Parasitology, 44(1), 25-32. https://doi.org/10.12816/0006443

Olival, K. J., Dick, C. W., Simmons, N. B., Morales, J. C., Melnick, D. J., Dittmar, K., Perkins, S. L., Daszak, P., \& DeSalle, R. (2013). Lack of population genetic structure and host specificity in the bat fly, Cyclopodia horsfieldi, across species of Pteropus bats in Southeast Asia. Parasites \& Vectors, 6(1), 231. https://doi.org/10.1186/1756-3305-6231

Piksa, K., Skwarek, M., \& Siuda, K. (2011). Argasid and spinturnicid mite load on swarming bats in the Tatra Mountains, Poland. Folia Parasitologica, 58(4), 322-325. https://doi.org/10.14411/fp.2011.033

Poerwanto, S. H., Ridhwan, L. R., Giyantolin, G., Ginawati, D., \& Paramitha, D. P. R. (2020). ECTOPARASITES DIVERSITY OF MICROCHIROPTERA BATS SUBORDER IN JEPANG CAVE, PLAWANGAN HILL, SLEMAN, YOGYAKARTA. Jurnal Veteriner, 21(4), 629-636. https://doi.org/10.19087/jveteriner.2020.21.4.629

Putra, M. I. H. (2014). Hubungan inang ektoparasit pada Kelelawar pemakan buah di Kampus Universitas Indonesia Depok = Host ectoparasite relationship on Fruit Bats in Universitas Indonesia Depok. Universitas Indonesia Library; Universitas Indoenesia. Fakultas Matematika dan Ilmu Pengetahuan Alam. http://lib.ui.ac.id

Sari, N. D., Putrisari, Fajar, M. F. R., Suwarni, S., \& Robiansah, D. (2015). Identifikasi Ektoparasit pada Kelelawar ( Chiroptera) di Gua Anjani, Purworejo, Jawa Tengah. https://123dok.com/document/y957m1jz-identifikasi-ektoparasit-kelelawar-chiropteraanjani-purworejo-jawa-tengah.html

Scheffler, I., Jargalsaikhan, A., Bolorchimeg, I., Stubbe, A., \& Stubbe, M. (2016). Bat Ectoparasites of Mongolia, Part 3. 16.

Stanko, M., Miklisová, D., Goüy de Bellocq, J., \& Morand, S. (2002). Mammal density and patterns of ectoparasite species richness and abundance. Oecologia, 131(2), 289-295. https://doi.org/10.1007/s00442-002-0889-5

Suyanto, A., Kartikasari, S. N., \& Pusat Penelitian dan Pengembangan Biologi (Indonesia). (2001). Kelelawar di Indonesia.

ter Hofstede, H. M., \& Fenton, M. B. (2005). Relationships between roost preferences, ectoparasite density, and grooming behaviour of neotropical bats. Journal of Zoology, 266(4), 333-340. https://doi.org/10.1017/S095283690500693X

Uchikawa, K., \& Kobayashi, T. (1979). A contribution to the ectoparasitic fauna of bats in Thailand. I. Fur mites of the family Myobiidae (Acarina; Trombidiformes). Acarologia, 20(3), 368-384.

Zabat, A. G., \& Eduardo, S. L. (2011). Some ectoparasites of the common rousette bat (Rousettus amplexicaudatus Geofroy, 1810 (Mammalia:Chiroptera:Pteropodidae)) from colonies in Batangas and Rizal, Philippines. Philippine Journal of Veterinary Medicine (Philippines). https://agris.fao.org/agris-search/search.do?recordID=PH2014000457 